\title{
Asupan Vitamin A, C, E, Dan IMT (Indeks Massa Tubuh) Pada Lansia Hipertensi dan Non Hipertensi Di Puskesmas Banyu Urip, Surabaya
}

\author{
Dietary Intake of Vitamin A, C, E, and Body Mass Index (BMI) Among Ederly \\ with Hypertension and Non Hypertension at Puskesmas Banyu Urip, Surabaya
}

\author{
Intan Putri Risky Amalia*, Erwin Astha Triyono ${ }^{1}$
}

\begin{abstract}
ABSTRAK
Latar Belakang: Hipertensi merupakan penyakit tidak menular dan mudah ditemui pada usia lansia. Asupan makanan memegang peranan penting dalam mencegah dan penatalaksanaan hipertensi.

Tujuan: Penelitian ini bertujuan untuk mengetahui hubungan antara asupan vitamin A, C, E dan IMT dengan hipertensi pada lansia di Puskesmas Banyu Urip Surabaya.

Metode: Penelitian ini menggunakan metode observasional dengan desain case control. Sampel penelitian ini dihitung sesuai dengan rumus Lemeshow yakni sebesar 32 responden (total kelompok kasus dan kontrol). Penelitian ini dilakukan pada bulan Juli hingga bulan Agustus 2018. Analisis statistik yang digunakan uji Chi Square.

Hasil: Sebagian besar responden berusia 66-70 tahun, berjenis kelamin wanita (87,5\%), riwayat pendidikan terakir SD sederajat (37,5\%), dan berkerja sebagai ibu rumah tangga (71,9\%). Tingkat kecukupan vitamin A sebagian besar baik (96,9\%). Tingkat kecukupan vitamin C sebagian besar kurang (87,5\%). Tingkat kecukupan vitamin E kurang (100\%). IMT sebagian besar responden normal $(59,4 \%)$. Tidak terdapat hubungan yang signifikan antara asupan vitamin $C$ dengan hipertensi (OR=3,462; $95 \% \mathrm{Cl}=0,32-37,473 ; p=0,300$ ) dan tidak terdapat hubungan yang signifikan IMT dengan hipertensi (OR=0,455; 95\% Cl=0,18-1,921; $p=0,236)$. Rata-rata asupan vitamin $\mathrm{A}$ pada responden hipertensi sebesar $1301,02 \pm 407,84$ ug dan pada tekanan darah normal 1968,03 $\pm 956,67$ ug. Ratarata asupan vitamin $\mathrm{E}$ pada responden hipertensi sebesar 3,06 $\pm 1,2 \mathrm{mg}$ dan pada tekanan darah normal sebesar $3,34 \pm 1,23 \mathrm{mg}$.

Kesimpulan: Asupan vitamin $C$ dan IMT tidak berhubungan signifikan dengan kejadian hipertensi. Rata-rata asupan vitamin A, C, dan E lebih besar pada responden kelompok tekanan darah normal.
\end{abstract}

Kata kunci: asupan vitamin A, vitamin C, vitamin E, Indeks Massa Tubuh, hipertensi

\begin{abstract}
Background: Hypertension is a non-comunicable disease that easy found in ederly. Dietary intake had an important role as prevent and manage hypertension.

Objectives: The objective of this study was to invistigate correlation of dietary intake of vitamins $A, C$, E and Body Mass Index (BMI) with hypertension among ederly at Puskesmas Banyu Urip Surabaya.

Methods: This study was observational that uses case-control desain. Samples calculated according Lemeshow formula amount of 32 respondent (total case and control). This study was held in July until August 2018. Statistical analysis use Chi Square.

Results: The result showed that most of subjects were 66-70 years old, woman (87.5\%), who had education history primary school (37.5\%), and work as house wife (71.9\%). Most of subject had adequate vitamin $A(96.9 \%)$, inadequate vitamin C (87.5\%) and inadequate vitamin $E(100 \%)$. BMI
\end{abstract}


most subject was normal (59.4\%). This study demostrated that there was no significant correlation between vitamin $C$ intake and hypertension ( $\mathrm{OR}=3.462 ; 95 \% \mathrm{Cl}=0.32-37.473 ; p=0.300)$, and no significant correlation between $\mathrm{BMI}$ and hypertension (OR=0.455; $95 \% \mathrm{Cl}=0.18-1.921 ; p=0.236$ ). Averange intake of vitamin $A$ in respondent hypertension was $1301.02 \pm 407.84 \mathrm{ug}$ and 1968.03 $\pm 407.84 \mathrm{ug}$ in respondent with normo tension. Averange intake of vitamin $E$ in respondent hypertension was $3.06 \pm 1.2 \mathrm{mg}$ and $3.34 \pm 1.23 \mathrm{mg}$ in respondent with normo tension.

Conclusions: There was no significant correlation between dietary intake vitamin $C$ and $B M I$ with hypertension. Averange intake of vitamin $A, C$, and $E$ was better in respondent with normo tension.

Keywords: dietary intake of vltamin A, vitamin C, vitamin E, Body Mass Index, hypertension.

\footnotetext{
*Koresponden:

amaliaintan.ai@gmail.com

${ }^{1}$ Defisi Penyakit Tropik-Infeksi, Departemen IImu Penyakit Dalam, RSUD Dr. Soetomo
}

\section{PENDAHULUAN}

Hipertensi merupakan penyakit tidak menular yang lebih sering ditemui pada kelompok usia lansia. Lansia merupakan golongan usia dengan prevalensi hipertensi tertinggi. Hipertensi mudah ditemui pada usia lansia karena pada lansia terjadi beberapa perubahan fisiologis contohnya menurunnya elastisitas pembuluh darah, berkurangnya respon baroreseptor, dan meningkatnya resistensi pembuluh darah perifer. Prevalensi hipertensi pada lansia usia 55-63 tahun sebesar 45,9\%; usia 65-74 tahun 57,6\%; dan usia 75 tahun $63,8 \%{ }^{1}{ }^{1}$ Jika hipertensi tidak segera dideteksi dan ditangani sedini mungkin, hipertensi dapat menjadi penyebab munculnya penyakit lain contohnya jantung, stroke, dan ginjal. $^{2}$ Hipertensi menjadi penyebab $12,8 \%$ kematian di dunia. $^{3}$

Hipertensi dapat dicegah dan ditangani dengan adanya pelayanan bagi penderita hipertensi. Penanganan hipertensi pada negara maju dilakukan dengan adanya kebijakan mengurangi penggunaan garam pada makanan yang diproses. ${ }^{4} \mathrm{Di}$ Indonesia, lebih dikenal dengan gerakan G4G1L5 (Gula 4 sendok Garam 1 sendok dan Lemak atau Minyak 5 sendok). Hipertensi dapat dicegah dengan melakukan modifikasi diet dan perubahan gaya hidup contohnya menjaga berat badan normal, beraktivitas fisik secara teratur, mengurangi konsumsi alkohol, menghindari kebiasaan merokok, dan mengendalikan stres. ${ }^{4,5}$ Asupan makanan atau modifikasi diet memegang peranan penting dalam mencegah hipertensi dan dapat dilakukan sebagai penatalaksanaan hipertensi. Pencegahannya dengan mengurangi asupan makanan yang mengandung natrium dan mengurangi konsumsi kafein. Sedangkan, penatalaksanaan hipertensi dari segi asupan dapat dilakukan dengan mengadopsi pola makan DASH (Dietary Approach to Stop Hypertension).

Dalam diet DASH terdapat anjuran untuk mengurangi konsumsi makanan yang mengandung lemak jenuh, total lemak, kolestrol, mengurangi konsumsi daging, pemanis dan gula. Selain itu, terdapat pula anjuran meningkatkan konsumsi sayur, buah, susu rendah lemak dan juga termasuk mengkonsumsi biji-bijian, ikan, hewan ternak, dan kacang-kacangan. ${ }^{6}$ Makanan yang disarankan dalam DASH kaya akan magnesium, kalium, kalsium, dan serat yang berhubungan dengan menurunnya tekanan darah. ${ }^{5}$ Penyajian sayuran dan buah-buahan dalam sehari yang disarankan oleh DASH mencapai 4-5 kali penyajian. Dalam sayuran dan buah-buahan terkandung vitamin, mineral, dan serat.

Vitamin yang terkandung dalam sayuran cukup beragam diantaranya terdapat vitamin A, B, C, E, dan K. Dari berbagai vitamin tersebut vitamin $A, C$, dan $E$ merupakan vitamin yang dapat berperan sebagai antioksidan. Antioksidan merupakan senyawa yang memiliki kemampuan untuk mendonorkan elektron dan bermanfaat dalam menghambat proses oksidasi. Antioksidan dapat mencegah dan menurunkan tingkat 
stres oksidatif terutama pada endotel karena antioksidan dapat merangsang produksi nitrit okside. ${ }^{7,8}$ Nitrit okside yang dihasilkan berperan dalam vasodilatasi. Asupan vitamin A, C, E yang rendah dapat menyebabkan menurunnya produksi nitrite okside sehingga dapat berpengaruh terhadap menurunnya kemampuan vasodilatasi. ${ }^{9}$ Selain itu, jika kadar antioksidan tidak lebih besar dari radikal bebas maka kolestrol dan lemak yang ada di pembuluh darah akan mudah mengalami oksidasi. Menurunnya kemampuan vasodilatasi pembuluh darah dapat menyebabkan meningkatnya tahanan perifer dan pada pembuluh darah ginjal menyebabkan penurunan glomerulus filtrasion rate (GFR) dan teraktivitasinya sistem renin angiotensin. ${ }^{9} \mathrm{Hal}$ tersebut dapat menyebabkan meningkatnya tekanan darah. Penelitian yang dilakukan oleh Regi (2017) mengenai hubungan tingkat kecukupan vitamin $A, C, E$ dan seng sebagai antioksidan dengan tekanan darah sistolik dan diastolik pada ibu hamil di puskesmas Bangetayu (Semarang) diperoleh adanya hubungan vitamin C dengan tekanan darah sistolik dan diastolik dan tidak ada hubungan antara vitamin $A, E$, dan seng dengan tekanan darah sistolik dan diastolik. ${ }^{7}$

Perubahan gaya hidup dan asupan makanan dapat berpengaruh terhadap status gizi. Status gizi merupakan salah satu dari faktor risiko hipertensi. ${ }^{10}$ Kurangnya aktivitas fisik dan meningkatnya gaya hidup sedentary serta maraknya makanan cepat saji yang mengandung tinggi kalori membuat meningkatnya status gizi obesitas. Status gizi obesitas dapat meningkatkan kemungkinan seseorang untuk mengalami hipertensi. Hasil penelitian yang dilakukan oleh Manampiring (2008) di Manado diperoleh adanya hubungan antara status gizi pada penduduk usia 45 tahun keatas dengan tekanan darah. ${ }^{11}$ Faktor risiko hipertensi meningkat 9 kali pada seseorang yang memiliki status gizi obesitas. ${ }^{12}$

Lokasi penelitian ini di Puskesmas Banyu Urip Surabaya. Lokasi tersebut dipilih karena puskesmas Banyu Urip memiliki prevalensi hipertensi tertinggi diantara puskesmas lain di Surabaya yakni sebesar $60,5 \%$ pada tahun 2015. ${ }^{13}$ Penelitian ini perlu dilakukan karena penelitian mengenai hubungan asupan vitamin A, C, E dan IMT dengan hipertensi masih terbatas dan belum banyak dilakukan. Penelitian ini bertujuan untuk mengetahui hubungan antara asupan vitamin A, C, E dan IMT dengan hipertensi pada lansia di Puskesmas Banyu Urip Surabaya.

\section{METODE}

Penelitian ini merupakan jenis penelitian observasional dengan desain kasus kontrol dan dilakukan di Posyandu lansia yang ada di wilayah kerja Puskesmas Banyu Urip Kelurahan Banyu Urip, Kecamatan Sawahan, Surabaya. Pengumpulan data dilakukan pada bulan Juli hingga Agustus 2018.

Populasi penelitian ini adalah lansia yang menerima PMT (Pemberian Makanan Tambahan) di posyandu lansia yang ada di puskesmas Banyu Urip yaitu sebanyak 1261 orang. Sampel penelitian ini dihitung sesuai dengan rumus Lemeshow yakni sebesar 32 responden yang dipilih secara purposif dengan rincian 16 orang hipertensi (kelompok kasus) dan 16 orang memiliki tekanan darah normal (kelompok normal). ${ }^{14}$ Bagi lansia yang bersedia menjadi responden akan diminta untuk menandangani informed consent. Variabel penelitian ini meliputi variabel bebas dan variabel terikat. Variabel terikat penelitian ini adalah kejadian hipertensi. Variabel bebas penelitian ini adalah usia, jenis kelamin, pedidikan, pekerjaan, IMT, rata-rata asupan vitamin $A, C$, dan E.

Pengumpulan data dilakukan menggunakan wawancara terstruktur diantaranya terdapat kuisioner food recall, food record, pengukuran antropometri, dan pengukuran tekanan darah. Data usia, jenis kelamin, pendidikan, dan pekerjaan diperoleh dari kuisioner wawancara. Data antropometri diperoleh melalui pengukuran tinggi badan menggunakan microtoise dan pengukuran berat badan menggunakan timbangan digital (merk GEA no. seri EB9360). Pengukuran berat badan dan tinggi badan dilakukan oleh peneliti dan enumerator. Sedangkan, data tekanan darah sistolik dan diastolik diperoleh dari pengukuran tekanan darah menggunakan sphygnomanometer digital (merk Omron no. seri hem 8712). Pengukuran tekanan darah dilakukan oleh petugas puskesmas Banyu 
Urip. Data asupan makanan diperoleh dari food recall dilakukan sebanyak $6 \times 24 \mathrm{~h}$ yang dilakukan baik pada hari kerja atau hari libur dan food record sebanyak $1 \times 24 \mathrm{~h}$. Food recall dilakukan sebanyak 6 kali untuk menyesuaikan reproducibility dari vitamin $A$ dan vitamin $A, C$, dan $\mathrm{E}^{15}$ Reproducibility berfungsi dalam ketelitiannya pada pengukuran eror, hasil tidak menentu dari variasi hari, dan keragaman dari berbagai faktor (contohnya faktor usia, cuaca, dan kesakitan). Data asupan vitamin $A, C, E$ yang digunakan dalam penelitian ini merupakan hasil rata-rata dari recall dan record.

Pengkategorian kecukupan vitamin A bagi wanita sebagai berikut kurang ( $<500 \mathrm{ug}$ ), baik (500 - >500 ug), dan lebih (>3.000 ug). ${ }^{16}$ Sedangkan kecukupan vitamin A bagi pria sebagai berikut kurang ( $<600 \mathrm{ug}$ ), baik (600$<600 \mathrm{ug}$ ), dan lebih (>3.000 ug) ${ }^{16}$ Kategori kecukupan vitamin $C$ bagi wanita sebagai berikut kurang ( $<75 \mathrm{mg}$ ), baik $(\geq 75 \mathrm{mg})$, dan lebih $(\geq 2.000 \mathrm{mg}){ }^{16}$ Sedangkan kategori kecukupan vitamin $C$ bagi bagi pria sebagai berikut kurang $(<90 \mathrm{mg})$, baik $(\geq 90 \mathrm{mg})$, dan lebih $(\geq 2.000 \mathrm{mg}){ }^{16}$ Kategori kecukupan vitamin $E$ bagi reponden sebagai berikut kurang ( $<15 \mathrm{mg}$ ), baik ( $\geq 15 \mathrm{mg}$ ), dan lebih $(\geq 1.000 \mathrm{mg}){ }^{16}$ Kategori IMT pada responden dibagi menjadi 2 yakni obesitas dan normal. Kategori IMT pada penelitian ini sesuai dengan kategori IMT untuk Asia. ${ }^{17}$ Cut off IMT tergolong obesitas apabila melebihi $27 \mathrm{~kg} / \mathrm{m}^{2}$.

Analisis statistik yang digunakan dalam penelitian ini yaitu analisis univariat dan analisis bivariat. Analisis univariat dilakukan untuk mengetahui gambaran karakteristik responden dan analisis bivariat digunakan dengan menggunakan uji Chi-Square untuk mengetahui hubungan antara variabel terikat dan variabel bebas.

Penelitian ini telah disetujui oleh Komisi Etik Penelitian Kesehatan Fakultas Kesehatan Masyarakat Universitas Airlangga (No. 465KEPK), ijin dari Badan Kesatuan Bangsa, Politik dan Perlindungan Masyarakat Kota Surabaya (No. 070/ 4287/436.8.5/2018), dan Dinas Kesehatan Kota Surabaya (No. 072/2/21087/436.7.2/2018).

\section{HASIL DAN PEMBAHASAN}

Berdasarkan tabel 1 diperoleh sebagian besar responden hipertensi berusia 66-70 tahun $(43,8 \%)$. Sedangkan, responden yang memiliki tekanan darah sebagian besar berusia 61-65 tahun (37,5\%). Sebagian besar responden adalah wanita $(87,5 \%$ dan $87,5 \%)$. Pendidikan terakhir responden hipertensi kebanyakan SD sederajat sebanyak 8 orang (50\%) dan pada responden tekanan darah normal sebagian besar memiliki pendidikan terakhir SMP sederajat sebanyak 6 orang $(37,5 \%)$. Sebagian besar pekerjaan responden adalah ibu rumah tangga (68,8\% dan $75 \%$ ). Responden yang memiliki tekanan darah normal sebagian besar IMT nya tergolong normal $(68,8 \%)$.

Berdasarkan tabel 1, diperoleh tingkat kecukupan vitamin A seluruh responden hipertensi baik $(100 \%)$ dan pada responden tekanan darah normal tergolong baik $(93,8 \%)$. Kecukupan vitamin C pada responden hipertensi $(93,8 \%)$ dan pada responden tekanan darah normal tergolong kurang (81,3\%). Kecukupan vitamin $\mathrm{E}$ seluruh responden tergolong kurang $(100 \%$ dan $100 \%)$.

Berdasarkan tabel 1, diperoleh tidak terdapat hubungan usia dengan kejadian hipertensi $(p=0,373)$. Meski terdapat teori bahwa seiring dengan bertambahnya usia meningkat pula risiko terjadinya hipertensi namun pada penelitian ini tidak ditemukan hubungan usia dengan hipertensi. ${ }^{18}$ Hasil penelitian ini sesuai dengan hasil penelitian Novitaningtyas (2014) yang diperoleh tidak terdapat hubungan usia dengan hipertensi pada lansia dan tidak sesuai dengan penelitian Siringoringo (2013) yang ditemukan adanya hubungan usia dengan hipertensi. ${ }^{19,20}$ Hasil penelitian ini berbeda dengan hasil penelitian Sriringoringo karena terdapat beberapa perbedaan diantaranya motode penelitian Sriringoringo menggunakan desain penelitian cross sectional dan keseluruhan responden kebanyakan berusia 45-59 tahun. Usia lansia lebih berisiko terkena hipertensi karena seiring bertambahnya usia elastisitas 
pembuluh darah menurun, menurun pula kemampuan kantup jantug memompa darah, meningkatnya resistensi perifer, dan menurunnya sensitivitas baroreseptor. ${ }^{21,22}$ Berkurangnya elastisitas pembuluh darah menyebabkan adanya peningkatan resistensi perifer. Resistensi perifer dan cardiac output dapat mempengaruhi tekanan darah. Sedangkan menurunnya sensititas baroreseptor dapat berpengaruh terhadap tekanan darah karena baroreseptor dapat mengirimkan impuls ke medula oblongata untuk menurunkan tekanan darah. Baroreseptor dapat mengurangi aktivitas saraf simpatis dan meningkatkan vasodilatasi. ${ }^{23}$ Hasil penelitian ini usia tidak berhubungan dengan hipertensi karena terdapat beberapa variabel lain yang dapat berpengaruh pada tekanan darah dan tidak diteliti dalam penelitian ini contohnya variabel asupan makanan (makronutrien), asupan kolestrol, lama waktu beristirahat, tingkat stres, tingkat aktivitas fisik, riwayat hipertensi, penggunaan

Tabel 1. Tabulasi Silang

\begin{tabular}{|c|c|c|c|c|c|c|c|}
\hline \multirow{2}{*}{ Variabel } & \multicolumn{2}{|c|}{ Hipertensi } & \multicolumn{2}{|c|}{ Normal tensi } & \multirow[t]{2}{*}{ p value } & \multirow[t]{2}{*}{ OR } & \multirow[t]{2}{*}{$95 \% \mathrm{Cl}$} \\
\hline & $\mathrm{n}$ & $\%$ & $\mathbf{n}$ & $\%$ & & & \\
\hline \multicolumn{8}{|l|}{ Usia } \\
\hline 55-60 tahun & 1 & 6,3 & 4 & 25 & \multirow{4}{*}{0,373} & & \\
\hline 61-65 tahun & 5 & 31,3 & 6 & 37,5 & & 0,3 & $0,025-3,626$ \\
\hline $66-70$ tahun & 7 & 43,8 & 5 & 31,3 & & 0,179 & 0,015-2,119 \\
\hline 71-75 tahun & 3 & 18,8 & 1 & 6,3 & & 0,083 & $0,004-1,945$ \\
\hline \multicolumn{8}{|l|}{ Jenis Kelamin } \\
\hline Pria & 2 & 12,5 & 2 & 12,5 & \multirow[t]{2}{*}{0,7} & 1 & \multirow[t]{2}{*}{$0,123-8,128$} \\
\hline Wanita & 14 & 87,5 & 14 & 87,5 & & & \\
\hline \multicolumn{8}{|l|}{ Riwayat pendidikan } \\
\hline SD dan sederajat & 8 & 50 & 4 & 25 & \multirow{4}{*}{0,418} & & \\
\hline SMP dan sederajat & 5 & 31,3 & 6 & 37,5 & & 2,4 & $0,444-12,98$ \\
\hline SMA dan sederajat & 3 & 18,8 & 5 & 31,3 & & 3,333 & $0,515-21,584$ \\
\hline D1/D2/D3/S1 & 0 & 0 & 1 & 6,3 & & 0,33 & $0,15-0,742$ \\
\hline \multicolumn{8}{|l|}{ Pekerjaan } \\
\hline Pensiunan & 2 & 12,5 & 2 & 12,5 & \multirow{4}{*}{0,799} & 1,091 & $0,13-9,124$ \\
\hline Ibu rumah tangga & 11 & 68,8 & 12 & 75 & & 0,5 & $0,188-1,332$ \\
\hline Pedagang & 1 & 6,3 & 0 & 0 & & 1 & $0,063-15,988$ \\
\hline Lainnya & 2 & 12,5 & 2 & 12,5 & & & \\
\hline \multicolumn{8}{|l|}{ IMT } \\
\hline Normal & 8 & 50 & 11 & 68,8 & \multirow[t]{2}{*}{0,236} & 0,455 & \multirow[t]{2}{*}{$0,18-1,921$} \\
\hline Obesitas & 8 & 50 & 5 & 31,3 & & & \\
\hline \multicolumn{8}{|l|}{ Vitamin A } \\
\hline Kurang & 0 & 0 & 0 & 0 & \multirow{3}{*}{$* \mathrm{nA}$} & \multirow{3}{*}{$* n A$} & \multirow{3}{*}{$*_{\mathrm{nA}}$} \\
\hline Baik & 16 & 100 & 15 & 93,8 & & & \\
\hline Lebih & 0 & 0 & 1 & 6,3 & & & \\
\hline \multicolumn{8}{|l|}{ Vitamin C } \\
\hline Kurang & 15 & 93,8 & 13 & & \multirow{3}{*}{0,3} & \multirow{3}{*}{3,462} & \multirow{3}{*}{$0,32-37,473$} \\
\hline Baik & 1 & 6,3 & 3 & $\begin{array}{l}81,3 \\
188\end{array}$ & & & \\
\hline Lebih & 0 & 0 & 0 & 18,0 & & & \\
\hline \multicolumn{8}{|l|}{ Vitamin E } \\
\hline Kurang & 16 & 100 & 16 & 100 & \multirow{3}{*}{$* n A$} & $* n A$ & $* \mathrm{nA}$ \\
\hline Baik & 0 & 0 & 0 & 0 & & $n A$ & $n A$ \\
\hline Lebih & 0 & 0 & 0 & 0 & & & \\
\hline
\end{tabular}

${ }^{*} \mathrm{nA}=$ not avaible 
obat hipertensi, tingkat konsumsi kafein, konsumsi natrium, dan konsumsi kalium. Hasil penelitian ini diperoleh terdapat faktor protektif hipertensi pada usia 55-60 tahun dibanding usia 61-65 tahun sebesar 0,3. Faktor protektif pada usia 55-60 tahun jika banding usia 66-70 tahun sebesar 0,179. Sedangkan, faktor protektif pada usia 51-60 tahun jika dibandingkan usia 71-75 tahun sebesar 0,083.

Hasil penelitian ini diperoleh tidak terdapat hubungan antara jenis kelamin dengan hipertensi $(p=0,7)$. Sebagian besar responden pada penelitian ini adalah wanita $(87,5 \%)$. Sebagian besar reponden penelitian ini wanita karena mayoritas anggota posyandu lansia (penerima PMT) dan yang menghadiri posyandu lansia adalah wanita. Faktor risiko terjadinya hipertensi pada lansia meningkat baik pada jenis kelamin pria dan wanita. ${ }^{23}$ Namun, sebelum usia 50 tahun pria cenderung lebih memiliki risiko hipertensi dibanding wanita. Hal tersebut terjadi karena sebelum usia 50 tahun wanita masih terlindung oleh hormon esterogen. ${ }^{24}$ Hormon esterogen mampu mencegah kerusakan pembuluh darah dan dapat meningkatkan kadar HDL (High Density Lipoprotein) sehingga dapat mencegah terjadinya aterosklerosis. ${ }^{24}$ Faktor risiko hipertensi meningkat pada wanita setelah wanita memasuki masa menopause. Hasil penelitian ini diperoleh faktor risiko meningkat 1 kali pada jenis kelamin pria jika dibandingkan dengan wanita. Hasil penelitian ini sejalan dengan penelitian Noviningtyas dan Sringoringo yang tidak ditemukan adanya hubungan jenis kelamin dengan hipertensi. ${ }^{19,20}$ Meski jenis kelamin merupakan salah satu faktor risiko hipertensi, namun pada penelitian ini tidak ditemukan adanya hubungan jenis kelamin dengan kejadian hipertensi. Hipertensi dipengaruhi juga oleh beberapa variabel berikut yang tidak diteliti dalam penelitian ini contohnya asupan makanan (makronutrien), asupan kolestrol, lama waktu beristirahat, tingkat stres, tingkat aktivitas fisik, riwayat hipertensi, penggunaan obat hipertensi, tingkat konsumsi kafein, konsumsi natrium, dan konsumsi kalium.

Riwayat pendidikan sebagian besar responden hipertensi adalah SD sederajat (50\%) dan riwayat pendidikan responden tekanan darah normal sebagian besar SMP sederajat (37,5\%). Hasil penelitian ini diperoleh tidak terdapat hubungan riwayat pendidikan terakir responden dengan hipertensi $(p=0,418)$. Meski tekanan darah tidak berhubungan dengan riwayat pendidikan responden, namun responden yang hipertensi cenderung memiliki riwayat pendidikan SD. Pendidikan tidak mempengaruhi hipertensi secara langsung. Pendidikan berhubungan dengan tingkat pengetahuan, gaya hidup, kebiasaan merokok, konsumsi alkohol, dan kebiasaan berolahraga. ${ }^{25}$ Tingkat pendidikan yang rendah dapat mempengaruhi pola makan responden, pemilihan makan, dan aktivitas fisik. Hasil penelitian ini sama dengan penelitian Noviningtyas, Siringoringo, Iskandar dan Fitriani dimana tidak terdapat hubungan antara pendidikan dengan kejadian hipertensi. ${ }^{19,20,25,26}$ Hasil penelitian ini sesuai dengan teori bahwa riwayat pendidikan bukan merupakan salah satu dari faktor risiko hipertensi.

Pekerjaan sebagian besar responden hipertensi dan tekanan darah normal adalah ibu rumah tangga (68,8\% dan $75 \%$ ). Tidak terdapat hubungan pekerjaan dengan hipertensi $(p=0,799)$. Hasil penelitian ini sejalan dengan penelitian Fitriani, Siringoringo, dan Iskandar dimana tidak ditemukan adanya hubungan pekerjaan dengan kejadian hipertensi..$^{20,25,26}$ Pekerjaan tidak berpengaruh secara langsung dengan kejadian hipertensi. Stutus seseorang sebagai pekerja dapat mempengaruhi tingkat stres, aktivitas fisik, pendapatan, dan pemilihan makanan. Meski pekerjaan tidak berpengaruh namun terdapat beberapa faktor lain yang dapat mempengaruhi tekanan darah contohnya aktivitas fisik dan tingkat stress. Hasil penelitian ini sesuai dengan teori bahwa pekerjaan bukan merupakan salah satu faktor risiko terjadinya hipertensi.

Status gizi sebagian besar responden hipertensi tergolong obesitas (50\%). Status gizi reponden tekanan darah normal sebagian besar tergolong normal (62,5\%). Tidak terdapat hubungan IMT dengan tekanan darah sistolik $(p=0,236)$. Hasil penelitian ini sejalan dengan penelitian Siriringoringo dan Purnama yang ditemukan tidak terdapat hubungan IMT dengan kejadian hipertensi. 20,27 Hasil penelitian ini tidak sesuai dengan 
penelitian Fitriani yang menemukan adaya hubungan IMT dengan kejadian hipertensi. ${ }^{25}$ Status gizi merupakan salah satu faktor risiko dari hipertensi, namun dalam penelitian ini tidak ditemukan adanya hubungan IMT dengan kejadian hipertensi. ${ }^{23,24,28}$ Kejadian hipertensi di puskemas Banyu urip dapat disebabkan oleh faktor risiko lain yang tidak diteliti dalam penelitian ini contohnya asupan (makronutrien), asupan kolestrol, lama waktu beristirahat, tingkat stres, tingkat aktivitas fisik, riwayat hipertensi, penggunaan obat hipertensi, tingkat konsumsi kafein, konsumsi natrium, dan konsumsi kalium. Hasil penelitian ini diperoleh terdapat faktor protektif pada IMT normal sebesar 0,455 dibanding dengan IMT obesitas. Hasil penelitian pada studi lain diperoleh tekanan darah akan meningkat $6,6 \mathrm{mmHg}$ pada pria jika terdapat kenaikan berat badan sebesar $10 \%{ }^{10}$

Hasil penelitian ini tidak dapat dilakukan uji statistik hubungan asupan vitamin $A$ dengan kejadian hipertensi karena data yang terkumpul termasuk dalam 1 kategori yaitu sebagian besar responden asupan vitamin $A$ tergolong cukup. Berdasarkan tabel 2, hasil penelitian ini diperoleh rata-rata asupan vitamin A pada kelompok hipertensi sebesar $1301,02 \pm 407,84$ ug dan pada kelompok tekanan darah normal sebesar 1968,03 $\pm 956,67$ ug. Rata-rata asupan vitamin A lebih baik pada reponden kelompok tekanan darah normal. Terdapat hasil penelitian yang dilakukan di Ohasama yang menunjukkan meski tidak terdapat hubungan signifikan asupan tinggi vitamin $\mathrm{A}$ dengan berkurangnya risiko hipertensi, namun ada kecenderungan konsumsi vitamin A dapat menurunkan risiko hipertensi. ${ }^{5}$ Vitamin $A$ dapat berhubungan dengan hipertensi karena $\beta$-karotein yang merupakan prekursor vitamin $A$ dapat berperan sebagai antioksidan. $\beta$-karotein dapat berkerja sama vitamin $E$ dalam mencegah oksidasi lemak dari radikal perokside dan hidroksil pada membran. ${ }^{30}$ Satu molekul $\beta$-karotein dapat menghilangkan 1000 oksigen bebas sebelum bereaksi. ${ }^{30}$ Sebelumnya, diketahui bahwa radikal bebas dapat menyebabkan stress oksidatif hingga kerusakan endotel. Vitamin A dapat mencegah terjadinya oksidasi lemak pada membran sehingga mampu menstimulus produksi nitride okside yang berhubungan dengan vasodilatasi. Selain itu, $\beta$-karotein juga berfungsi dalam mengaktifkan antioksidan enzimatik pertahanan kedua yakni glutatione S-transferase. ${ }^{31}$ Hasil penelitian lain yang mengkaji hubungan serum $A$ dengan tekanan darah diperoleh terdapat hubungan positif. ${ }^{32}$ Sebagian besar responden dengan hipertensi dan responden yang memiliki tekanan darah normal memiliki asupan vitamin A yang baik (100\% dan 93,8\%).

Kecukupan vitamin C pada sebagian besar responden hipertensi dan tekanan darah normal tergolong kurang $(93,8 \%$ dan $81,3 \%)$. Hasil penelitian ini diperoleh tidak terdapat hubungan vitamin $\mathrm{C}$ dengan hipertensi $(p=0,3)$. Hasil penelitian ini tidak sesuai dengan penelitian Regi dkk (2017) yang menemukan adanya hubungan kecukupan vitamin $\mathrm{C}$ dengan tekanan sistolik dan tekanan darah diastolik. ${ }^{7}$ Namun, hasil penelitian ini sesuai dengan hasil penelitian Andamsari dkk (2015) di Minangkabau yang meneliti mengenai pola makan dengan tekanan darah dan diperoleh tidak terdapat hubungan konsumsi vitamin $\mathrm{C}$ dengan tekanan darah. Tingginya asupan vitamin $C$ diperoleh dari asupan buah dan sayur sehari-hari. Risiko hipertensi berkurang pada seseorang yang mengkonsumsi makanan yang mengandung asupan vitamin $\mathrm{C}$, buah dan sayur-sayuran. ${ }^{5}$ Vitamin C merupakan vitamin yang dapat berperan sebagai antioksidan sehingga vitamin C mampu mendonorkan elektronnya untuk mencegah terjadinya stres oksidatif. Bentuk aktif vitamin $\mathrm{C}$ dalam sistem redok diantaranya L-asam askorbat, free radical monodehydro L-asam askorbat (AFR), dan oxsidized askorbat atau dehydro L-asam askorbat (DHA). ${ }^{33}$ Vitamin C sebagai antioksidan mampu mengganggu produksi radikal bebas dan peroksida. ${ }^{34}$ Vitamin $\mathrm{C}$ dapat meningkatkan sintesis prostagladine yang berhubungan dengan vasodilatasi. ${ }^{34}$ Hasil penelitian ini tidak menemukan adanya hubungan vitamin $\mathrm{C}$ dengan hipertensi karena terdapat kemungkinan responden pada penelitian ini ada yang memiliki kebiasaan merokok dan tidak diteliti dalam penelitian ini. Kebiasaan merokok dapat meningkatkan produksi radikal bebas didalam tubuh. Jika 
Tabel 2. Rata-rata Asupan Vitamin Pada Responden

\begin{tabular}{lcc}
\hline Asupan Vitamin & Kelompok Hipertesi & Kelompok Normotensi \\
\hline Vitamin A & $1301,02 \pm 407,84 \mathrm{ug}$ & $1968,03 \pm 956,67 \mathrm{ug}$ \\
\hline Vitamin C & $38,67 \pm 42,91 \mathrm{mg}$ & $40,25 \pm 33,16 \mathrm{mg}$ \\
\hline Vitamin E & $3,06 \pm 1,2 \mathrm{mg}$ & $3,34 \pm 1,23 \mathrm{mg}$ \\
\hline
\end{tabular}

terjadi ketidakseimbangan kadar radikal bebas dan antioksidan maka dapat menyebabkan terjadinya stress oksidatif.

Seseorang yang memiliki kebiasaan merokok memerluhkan asupan makanan yang mengandung antioksidan (vitamin C) yang lebih besar dibandingkan seseorang yang tidak memiliki kebiasaan merokok.

Reponden yang memiliki tekanan darah normal sebagian besar juga memiliki kecukupan vitamin C yang kurang $(81,3 \%)$.

Berdasarkan tabel 2, diperoleh rata-rata asupan vitamin $C$ pada kelompok hipertensi sebesar $38,67 \pm 42,91 \mathrm{mg}$ dan pada kelompok tekanan darah normal sebesar 40,25 $\pm 33,16$ mg. Asupan vitamin $\mathrm{C}$ pada kelompok tekanan darah normal lebih baik dibandingkan kelompok hipertensi. Hipertensi dipengaruhi juga oleh beberapa variabel berikut yang tidak diteliti dalam penelitian ini contohnya asupan makanan (makronutrien), asupan kolestrol, lama waktu beristirahat, tingkat stres, tingkat aktivitas fisik, riwayat hipertensi, penggunaan obat hipertensi, tingkat konsumsi kafein, konsumsi natrium, dan konsumsi kalium.

Kecukupan vitamin $\mathrm{E}$ pada reponden hipertensi dan tekanan darah normal tergolong kurang (100\% dan 100\%). Hasil penelitian ini tidak dapat dilakukan uji analisis statistik hubungan asupan vitamin $\mathrm{E}$ dengan kejadian hipertensi karena data yang terkumpul tergolong dalam 1 kategori. Berdasarkan tabel 2, rata-rata asupan vitamin E pada responden kelompok hipertensi sebesar 3,06 $\pm 1,2 \mathrm{mg}$ dan pada responden kelompok tekanan darah normal sebesar 3,34 $\pm 1,23 \mathrm{mg}$. Asupan vitamin E lebih baik pada kelompok responden tekanan darah normal dibandingkan hipertensi. Hasil penelitian Regi dkk (2017) diperoleh tidak terdapat hubungan vitamin $\mathrm{E}$ dengan tekanan darah sistolik dan diastolik. ${ }^{7}$ Vitamin E dapat berfungsi sebagai antioksidan yang dapat mencegah peroksidasi lemak. ${ }^{35}$ Vitamin $\mathrm{E}$ dapat bereaksi dengan radikal peroksil 1000 kali lebih cepat dibanding radikal peroksil bereaksi dengan asam lemak tidak jenuh. ${ }^{36}$ Meningkatnya asupan vitamin yang dapat berperan sebagai antioksidan dapat menjaga keseimbangan radikal bebas dan antioksidan dalam tubuh. Hal ini dapat menghindari terjadinya oksidasi lemak yang mampu menurunkan elastisitas pembuluh darah.

\section{KESIMPULAN}

Hasil penelitian ini diperoleh, tidak terdapat hubungan asupan vitamin C dan IMT dengan hipertensi. Rata-rata asupan vitamin A, C, dan E lebih baik pada responden kelompok tekanan darah normal. Terdapat beberapa variabel lain yang dapat berpengaruh dengan kejadian hipertensi contohnya asupan kolestrol, lama waktu beristirahat, genetik, kebiasaan merokok, konsumsi alkohol, tingkat aktivitas fisik, dan tingkat stres namun tidak diteliti dalam penelitian ini.

\section{ACKNOWLEDGEMENT}

Peneliti mengucapkan terimakasih banyak kepada semua pihak yang terlibat dalam penelitian ini. Ucapan terima kasih juga peneliti tujukan untuk seluruh dosen dan staf Prodi Gizi Universitas Airlangga khususnya Bapak Trias Mahmudiono atas bimbingan yang telah diberikan pada peneliti.

\section{REFERENSI}

1. Kemenkes. Elderly Condition in Indonesia. Report 8 (2016). doi:ISSN 2442-7659

2. James, P. A. et al. 2014 Evidence-Based Guideline for the Management of High Blood Pressure in Adults. Jama 311, 507 (2014).

3. World Health Organization. Global health observatory data: raised blood 
pressure. WHO Rais. blood Press. 39-40 (2016).

4. World Health Organization. A Global Brief on Hypertension. [e-book] Avaible from

https://doi.org/10.1136/bmj.1.4815.88

2-a. Diakses pada 27 Agustus 2018

5. Utsugi, M. T. et al. Fruit and vegetable consumption and the risk of hypertension determined by self measurement of blood pressure at home: the Ohasama study. Hypertens. Res. 31, 1435-1443 (2008).

6. US. Department Of Health and Human Service. (2006). Lowering Your Blood Pressure With DASH. Blood, 64. https://doi.org/10.1037/e566492010001. Diakses pada 28 Agustus 2018

7. Regi, Hillari Dita., Martha, Irene Kartasurya., Suyatno. Hubungan Tingkat Kecukupan Vitamin A, C, E Dan Seng Sebagai Antioksidan Dengan Tekanan Darah Sistolik Dan Diastolik Pada Ibu Hamil Di Puskesmas Bangetayu Kota Semarang. JKM E-journal, 5 (4), 683689.

8. Saputri, Adinda Trisni. Asupan Antioksidan ( Betakaroten, Vitamin C, Vitamin E ) Dan Status Hipertensi Pasien Rawat Jalan Di Poli Penyakit Dalam Rsud Cibabat Cimahi Bandung. Tesis. Bandung, 2015. p.2-3.

9. Sulastri, D. \& Liputo, N. I. Konsumsi Antioksidan dan Ekspresi Gen eNOS3 Alel -786T>C pada Penderita Hipertensi Etnik Minangkabau. Maj. Kedokt. Bandung 43, 1-9 (2011).

10. Setyan, U. Konsep Dasar Hipertensi. 5 (2009).

11. Manampiring, A. E. Hubungan Status Gizi dan Tekanan Darah Pada Penduduk Usia 45 Tahun ke Atas di Kelurahan Pakowo Kecamatan Wanea Kota Manado. Universtas Sam Ratulangi (2008).

12. Nurarima, A. Faktor Risiko Hipertensi pada Masyarakat di Desa Kabongan Kidul, Kabupaten Rembang. Media Medika Muda (2012).

13. Dinas Kesehatan Kota Surabaya. Gambaran Umum Dinas Kesehatan. Diakses

pada http://dinkes.surabaya.go.id/portal/pro fil/. Diakses pada 28 Agustus 2018.

14. Lemeshow, S., Hosmer Jr, D. W., Klar, J. \& Lwanga, S. K. Part 1: Statistical Methods for Sample Size Determination. Adequacy Sample Size Heal. Stud. 247 (1990). doi:10.1186/1472-6963-14-335

15. Gibson, Rosalind S. Principles of Nutritional Assessment. USA, 2005

16. Permenkes. Peraturan Menteri Kesehatan Republik Indonesia Nomor 75 Tahun 2013 Tentang Angka Kecukupan Gizi Yang Dianjurkan Bagi Bangsa Indonesia. Menkes RI 1-10 (2013).

17. Depkes. Pedoman Praktis Memantau Status Gizi Orang Dewasa. http://gizi.depkes.go.id/wpcontent/uploads/2011/10/ped-praktisstat-gizi-dewasa.doc tahun 2011. Diakses pada 29 Agustus 2018.

18. Supraptia, B., Nilamsari, W. P., Hapsari, P. P., Muzayana, H. A. \& Firdausi, H. Permasalahan Terkait Obat Antihipertensi pada Pasien Usia Lanjut di Poli Geriatri RSUD Dr.Soetomo Surabaya. J. Farm. dan IImu Kefarmasian Indones. 1, 36-41 (2014).

19. Novitaningtyas, T. Hubungan Karakteristik (Umur, Jenis Kelamin, Tingkat Pendidikan) Dan Aktivitas Fisik Dengan Tekanan Darah Pada Lansia Di Kelurahan Makamhaji Kecamatan Kartasura Kabupaten Sukoharjo. Univ. Muhammadiyah (2014).

20. Siringoringo, M., Hiswani \& Jemadi. Faktor - Faktor Yang Berhubungan Dengan Hipertensi Pada Lansia Di Desa Sigaol Simbolon Kabupaten Samosir Tahun 2013. Gizi, Kesehat. Reproduksi dan Epidemiol. 2, 1-10 (2014).

21. Kuswardhani, R. T. Penatalaksanaan Hipertensi Pada Lanjut Usia. J Peny Dalam 7, 135-140 (2006).

22. Pasaribu, D. M. R., Korespondensi, A., Terusan, J., No, A. \& Barat, J. Patogenesis Virus Hepatitis B. J. Univ. Kristen Krida Wacana (2014).

23. Siyad, A. . Hypertension. Hygeia J. Drugs Med. 3, 1-16 (2011).

24. Nuraini, B. Risk factors of hypertension. 
J Major. 4, 10-19 (2015).

25. Stotz, A. et al. Effect of a brief heat exposure on blood pressure and physical performance of older women living in the community-a pilot-study. Int. J. Environ. Res. Public Health 11, 12623-12631 (2014).

26. Iskandar dkk, R. Karakteristik Penderita Hipertensi di Puskesmas Titi Papan Kecamatan Medan Deli. 1-9 (2012).

27. Purnama, D. S. \& Prihartono, N. A. Prevalensi Hipertensi dan Faktor-Faktor yang Berhubungan dengan Kejadian Hipertensi Pada Lansia di Posyandu Lansia Wilayah Kecamatan Johar Baru Jakarta Pusat Tahun 2013 Abstrak Prevalence of Hypertension and Factors that Related with the Incidence of Hype. (2013).

28. O'Brien, E. ABC of hypertension: Blood pressure measurement. Bmj 322, (2001).

29. Reza, H. P., Lipoeto, N. I. \& Kadri, H. Artikel Penelitian Hubungan Konsumsi Makanan Sumber Antioksidan dan Omega-3 Terhadap Tekanan Darah Masyarakat di Sumatera Barat. 5, 409415 (2014).

30. McDowell, L., Wilkinson, N., Madison, R. \& Felix, T. Vitamins and minerals functioning as antioxidants with supplementation considerations. Florida Rumin. Nutr. Symp. 1-17 (2007).
31. Kaulmann, Anouk., Torsten Bohn. Carotenoid, Inflamation, and Oxidative stress-implications of Cellular Signaling Pathway and Relatopn To Choronic Disease Prevention tahun 2014. Elsivier. 34 :907-929. https://doi.org/10.1016/j.nutres.2014.0 7.010. Diakses pada tanggal 29 Agustus 2018.

32. Chen, J., He, J., Hamm, L., Batuman, V. \& Whelton, P. K. Serum antioxidant vitamins and blood pressure in the United States population. Hypertension 40, 810-816 (2002).

33. Erdman, John W., Jr., Ian A. Macdonald, and Steven H. Zeisel. Present Knowledge in Nutrition. Hongkong : Wiley-Blackwell; 2012.

34. Afrose, S. A., Fahmeed, A., Mujtaba, A., Khan, M. \& Noorulla, S. M. A Study on Effects of Combining Vitamin $C$ with Hypertension Therapy. 4, 142-146 (2015).

35. Almatsier, Sunita. Prinsip Dasar IImu Gizi. Jakarta : Gramedia; 2010.

36. Ross, A. Catherine, Benjamin Caballero, Robert J. Cousins, Katherine L. Tucker, Thomas R. Zigler. Modern Nutrition In Health and Disease. Eleventh Edition. [e-book]. Philadelphia: Wolters Kluwer; 2014. 